\title{
KINERJA INDIVIDU SEBAGAI DAMPAK PENERIMAAN TEKNOLOGI: PENDEKATAN MODEL UTAUT
}

\author{
Aditya Pandu Wicaksono, ${ }^{a,}$, Dekar Urumsah ${ }^{\mathrm{b}}$, Gilang Nugrohoc \\ $a, b, c$ Universitas Islam Indonesia, Jalan Kaliurang KM 14,5, Umbulmartani, \\ Ngemplak, Kabupaten Sleman, D.I. Yogyakarta \\ *(aditya.pandu@uii.ac.id)
}

\begin{abstract}
ABSTRAK
Teknologi informasi (TI) saat ini sudah menjadi saraf yang penting dalam menopang tubuh perusahaan. Selain itu, TI diharapkan dapat meningkatkan kinerja dan produktivitas karyawan. Oleh karena itu, Penelitian ini bertujuan untuk menguji penggunaan teknologi terhadap kinerja individu. Penelitian ini menggunakan variabel yang diambil dari unified theory of acceptance and use of technology (UTAUT) sebagai variabel yang mempengaruhi penggunaan teknologi dan kinerja individu. Penelitian ini adalah penelitian dengan pendekatan kuantitatif dengan menyebarkan kuesioner ke responden. Responden penelitian ini adalah karyawan di perusahaan pengembang perangkat lunak di Yogyakarta. Dengan teknik convenient sampling diperoleh 132 responden dan diolah dengan smartPLS. Hasil penelitian menemukan bahwa persepsi kenyamanan, pengaruh sosial, dan kondisi yang memfasilitasi berpengaruh positif dan signifikan terhadap penggunaan TI. Lebih lanjut, persepsi kenyaman, kondisi yang memfasilitasi, dan penggunaan TI berpengaruh positif signifikan terhadap kinerja individu. Kesimpulannya, penggunaan teknologi dipengaruhi oleh persepsi kenyamanan menggunakan teknologi, adanya pengaruh sosial, dan fasilitas yang tersedia yang kemudian akan meningkatkan kinerja individu. Penelitian ini mendorong perusahaan untuk menggunakan teknologi untuk meningkatkan kinerja individu.
\end{abstract}

Kata kunci: Kinerja Individu, Teknologi Informasi, UTAUT

\begin{abstract}
Nowadays, information technology (IT) was a fundamental tool for companies to bolster their activities. In Addition, the expectation of IT usage was able to enhance employees' performances and productivities. Furthermore, this research examines the influence of technology to individual performance. This research selected variables that available in unified theory of acceptance and use of technology (UTAUT) as variable which influencing IT usage and individual performances. This was a quantitative research by distributing questionnaire to employees of software developer companies in Yogyakarta as participants. Convenient sampling was applied and gathering 132 data which was executed using SmartPLS. This research finds perceived enjoyment, social influence, and facilitating condition is positively significant influencing IT usage. In other hand, perceived enjoyment, facilitating condition, and IT usage is positively and significantly influencing individual performances. In conclusion, IT usage is influenced by perceived enjoyment of IT usage, social influence, and facilitating
\end{abstract}


condition. Then, these variables are able to heighten individual performances. This research drives the companies to use and advance the IT to raise individual performances.

Keywords: Information Technology, Individual Performance, UTAUT

\section{PENDAHULUAN}

Di abad 20 ini perkembangan teknologi berkembang dengan sangat pesat dari waktu ke waktu. Inovasi dalam perkembangan sistem dan teknologi informasi (STI), peningkatan mobile devices, serta berkembangnya jaringan sosial dianggap sebagai sebuah transisi dari industri tradisional menjadi berbasis teknologi. Penggunaan teknologi memiliki peran penting dalam meningkatkan produktivitas dari perusahaan maupun karyawan yang bekerja di dalamnya. Bahkan, penggunaan teknologi akan berkaitan dengan pendapatan kerja dari karyawan serta meningkatkan komunikasi antar individu (Chesley dan Johnson 2015). Teknologi telah memberikan tambahan fasilitas atau cara untuk saling terhubung tanpa terkendala jarak dan waktu (Chesley 2005). Selain itu, dampak dari perkembangan STI disertai pengelolaan pengetahuan dapat memainkan peran penting untuk meningkatkan aspek inovasi dan kreatifitas (Gordon et al. 2008).
Akuntansi yang merupakan sebuah aktivitas untuk mencatat transaksi keuangan hingga menghasilkan laporan keuangan tidak terlepas dari penggunaan teknologi. Teknologi berperan untuk mengintegrasikan setiap divisi atau unit yang melakukan aktivitas keuangan untuk mendukung sistem pelaporan keuangan yang tepat waktu dan lebih komprehensif. Sangat sulit dibayangkan jika siklus akuntansi perusahaan terutama perusahaan besar tidak menggunakan sistem terintegrasi dalam sistem akuntansi (Balzli dan Morard 2012). Penggunaan STI dimaksudkan untuk mengelola sebagian atau seluruh sumber daya atau data perusahaan secara terkomputerisasi ke dalam database (Balzli dan Morard 2012).

Dalam bidang akuntansi manajemen, penggunaan teknologi seperti Flexible Manufacturing Systems, Computer-integrated System, dan Computer-aided Design akan memberikan manfaat dalam bentuk peningkatan produktivitas dan efektivitas dalam kegiatan 
manufaktur (Sriram 1995). Di sisi lain, penggunaan STI juga memberikan pengaruh pada peran seorang akuntan. Sistem seperti Enterprise Resource Planning (ERP) telah merubah pola kerja seorang akuntan dari pengelola data dan penyedia laporan keuangan menjadi petugas input data dan pemeriksa output dari sistem ERP (Chen et al. 2012). Namun demikian esensi dari penggunaan STI dalam rangka untuk meningkatkan efektivitas, efisiensi, produktivitas dari seorang pekerja (Chesley dan Johnson 2015), dan sebagai sebuah keunggulan kompetitif (Hidalgo dan Albors 2008).

Perusahaan baik multinasional maupun nasional telah secara signifikan mengubah strategi untuk menghadapi berbagai tekanan dan meningkatkan keunggulan kompetitif (Sriram 1995). Salah satu strategi yang digunakan adalah dengan menerapkan STI. Tetapi, penerimaan STI oleh seorang karyawan masih perlu diteliti apakah STI yang diimplementasikan diperusahaan memiliki dampak kepada mereka. Difusi, adopsi, dan penerimaan terhadap teknologi mengacu pada aspek yang saling melengkapi dengan dinamika manusia yang menjadi artifisial baru yang tertanam dalam kehidupan sosial maupun proses bisnis (Lindsay, Jackson, dan Cooke 2011).

Venkatesh et al. (2003) menyediakan sebuah tinjauan detail dari berbagai model yang berkaitan dengan adopsi dan penerimaan teknologi. Penelitian tersebut berhasil mengembangkan sebuah model yang disebut unified theory of acceptance and use of technology (UTAUT). UTAUT menekankan pada perilaku menggunakan teknologi yang didasarkan pada ekspektasi bahwa teknologi akan memberikan dampak terhadap performa (performance expextancy) dengan teknologi yang mudah digunakan (effort expectancy). Selain itu, perilaku teknologi juga dipengaruhi oleh pihak eksternal yang mempengaruhi (subjective norm) dan juga kondisi fasilitas yang tersedia. Penelitian dari Compeau, Higgins, dan Huff (1999) juga menekankan bahwa penggunaan teknologi didasari oleh apa yang akan diperoleh jika menggunakan teknologi (outcome expectancy).

Penelitian dengan menggunakan model UTAUT telah digunakan oleh beberapa penelitian di bidang adopsi dan penerimaan teknologi. Mckeown dan Anderson (2015) menggunakan UTAUT untuk melihat tingkat penerimaan teknologi antara mahasiswa sarjana dengan pascasarjana. Mosweu, Bwalya, dan 
Mutshewa (2016) menginvestigasi penerimaan teknologi document workflow management system (DWMS) dengan UTAUT dan Tarhini et al. (2016) menginvestigasi penerimaan teknologi internet banking. Namun demikian penelitian yang membahas bagaimana peran teknologi untuk kinerja individual (performance/outcome expectancy) belum banyak dilakukan. Penelitian dari Venkatesh et al. (2003) dan Compeau, Higgins, dan Huff (1999) memang telah menjelaskan performance/outcome expectancy yang dijadikan variabel independen dalam adopsi dan penerimaan teknologi tetapi belum menjelaskan hubungan lanjutannya terhadap kinerja individu setelah menggunakan teknologi.

Penelitian ini akan menguji penerimaan teknologi dengan model UTAUT yang kemudian diuji pengaruhnya terhadap kinerja individu. Penelitian ini menekankan pada dampak kinerja individu setelah teknologi diimplementasikan. Teori penerimaan teknologi yang ada belum menjelaskan hal ini sehingga penelitian ini mengkonfirmasi performance expectancy dalam model UTAUT untuk mengetahui pengaruh teknologi terhadap kinerja yang nyata (actual performance). Selain itu, penelitian ini menggunakan variabel diluar UTAUT yaitu persepsi kenyamanan (perceived enjoyment) yang dikembangkan dalam penelitian (Davis, Bagozzi, dan Warshaw 1992). Perusahaan perangkat lunak di Yogyakarta dipilih menjadi objek penelitian karena masih jarang penelitian dilakukan di area ini mengingat perusahaan ini sangat erat kaitannya dengan STI.

\section{TELAAH LITERATUR DAN} PERUMUSAN HIPOTESIS

\section{Teori Adopsi dan Penerimaan Teknologi}

Teori adopsi dan penerimaan teknologi yang ada sekarang ini seperti UTAUT pada awalnya dibangun oleh teori keperilakuan yaitu social cognitive theory (Bandura 1977; Bandura 1999). Social cognitive theory merupakan teori keperilakuan yang melihat individu berperilaku dari dua konseptual yang mempengaruhi perilaku individu (Compeau dan Higgins 1995) dengan banyak dimensi di dalamnya. Akan tetapi, Bandura mengedepankan dua pokok harapan sebagai faktor yang mendorong terjadinya perilaku. Pokok pertama terkait dengan keluaran atau outcome, individu akan cenderung melakukan perilaku jika mereka percaya bahwa akan menghasilkan outcome daripada mereka tidak melakukan perilaku yang memberikan konsekuensi 
keuntungan. Kedua, keahlian diri atau self-efficacy merupakan sebuah keyakinan dari individu untuk menampilkan suatu perilaku. Selfefficacy mempengaruhi pilihan individu untuk berperilaku dilihat dari kemampuan untuk menanggulangi kendala dalam menampilkan perilaku. Selanjutnya, individu mencari lingkungan yang ada untuk menambah pengaruh untuk melakukan suatu perilaku. Sehingga, perilaku yang dilakukan merupakan keluaran atas adanya pengaruh dari lingkungan. Dengan demikian terdapat sebuah transaksi antara faktor person (afektif dan kognitif), lingkungan, dan perilaku yang saling mempengaruhi.

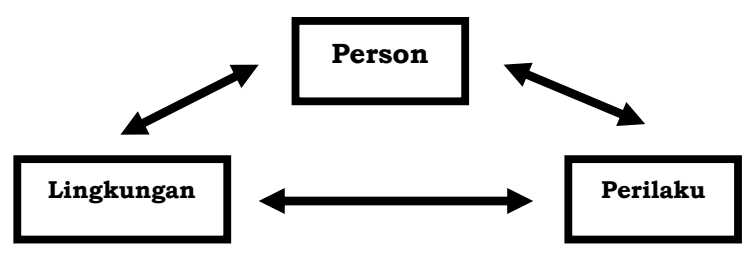

Gambar 1. Resiprokal

Determinasi (Compeau dan Higgins

$$
\text { 1995) }
$$

Dalam perkembangannya, outcome penggunaan teknologi merupakan hal yang sangat diharapkan bahwa penggunaan teknologi memiliki dampak terhadap pengguna. Davis, Bagozzi, dan Warshaw (1992) dalam penelitiannya menggunakan penerimaan teknologi menggunakan teori motivasi dari Deci
(1972) yang dilihat dari dua perspektif umum, yaitu ekstrinsik dan intrinsik motivasi. Ekstrinsik motivasi menekankan bahwa individu menggunakan teknologi dipersepsikan sebagai jalan untuk mendapatkan outcome atau penghargaan seperti meningkatnya kinerja, gaji, dan promosi jabatan. Sedangkan intrinsik motivasi merupakaan kesadaran penggunaan teknologi tanpa ada dorongan yang jelas selain proses aktivitas itu sendiri.

Bagaimana suatu pengaruh dari outcome penggunaan sangat penting untuk mendorong menggunakan teknologi telah dibuktikan dalam penelitian Davis, Bagozzi, dan Warshaw (1992). Penelitian tersebut menjelaskan bahwa ekstrinsik motivasi merupakan pengaruh utama dalam penerimaan teknologi. Secara lebih lanjut dijelaskan bahwa teori penerimaan teknologi yang dikenal sebagai theory acceptance model (TAM) (Davis 1989) yang terdiri dari dua variabel pokok yaitu persepsi kebergunaan (perceived usefulness) dan persepsi kemudahan (ease of use) merupakan bentuk transformasi dari ekstrinsik motivasi.

Ekstrinsik motivasi merupakan landasan utama dalam terbentuknya teori-teori penerimaan teknologi. Individu yang menggunakan teknologi 
memiliki ekspektasi untuk mampu memberikan pengaruh yang positif terhadap dirinya dalam hal peningkatan kinerja dan juga karir. Oleh karena itu pengembangan teori penerimaan teknologi lebih mengedepankan pada ekstrinsik motivasi seperti dalam UTAUT. Namun demikian, instrinsik motivasi tidak begitu saja ditinggalkan dalam pengujian penerimaan teknologi. UTAUT (Venkatesh et al. 2003) menggunakan intrinsik motivasi sebagai variabel moderasi yang penggunaannya untuk mengetahui apakah dengan adanya ditambah dengan intrinsik motivasi penerimaan teknologi akan semakin tinggi. Intrinsik motivasi dalam UTAUT ditransformasikan ke dalam variabel kesukarelaan (voluntariness of use) dan pengalaman (experience).

\section{Unified Theory of Acceptance and Use of Technology (UTAUT)}

Teori ini muncul dari model penelitian yang dibangun oleh Venkatesh et al. (2003) yang merupakan hasil kajian dari berbagai teori baik teori penerimaan teknologi maupun teori keperilakuan. UTAUT menggabungkan TAM dan theory of planned behavior (TPB) (Ajzen 1991) (walaupun masih ada penelitian lain seperti Thompson, Higgins, dan Howell 1991; Moore dan Benbasat
1991) untuk menginvestigasi niat menggunakan teknologi dan dilanjutkan dengan menggunakan teknologi yang nyata.

Model UTAUT di atas mengadopsi variabel-variabel yang ada dalam TAM sehingga memiliki makna yang sama. Variabel performance expectancy dan effort expectancy adalah istilah lain untuk perceived usefulness dan perceived ease of use dalam model TAM. Social influence mempunyai arti yang sama dengan subjective norm di TPB, sedangkan facilitating condition merupakan transformasi dari perceived behavioral control di TPB. Niat (behavioral intention) dan perilaku penggunaan teknologi (use behavior) mengadopsi dalam model dan juga penggunaan variabel tersebut seperti dalam TPB.

\section{Kinerja Individu dengan Teknologi}

Berbagai teori dalam adopsi dan penerimaan teknologi seperti TAM dan UTAUT pada umumnya hanya menjelaskan persepsi manfaat sehingga teknologi tersebut akan diterima. Persepsi manfaat diberi istilah yang berbeda-beda dalam penelitian seperti perceived usefulness (Davis 1989), performance expectancy (Venkatesh et al. 2003), outcome expectancy (Compeau, Higgins, dan Huff 1999), dan job-fit (Thompson, 
Higgins, dan Howell 1991). Namun demikian penjelasan tersebut hanya sebatas persepsi dalam perilaku penerimaan teknologi yang belum menjelaskan bagaimana dampak yang sebenarnya manfaat teknologi untuk kinerja karyawan perusahaan yang sebenarnya.

Di era sekarang ini, perusahaan menerapkan teknologi bukanlah sesuatu yang baru bahkan cenderung suatu kebutuhan yang harus ada untuk peningkatan efisien, efektifitas, dan produktivitas. Penelitian yang dilakukan Mano dan Mesch (2010) menguji dampak penggunaan e-mail yang hubungannya dengan performa pekerjaan atau kinerja karyawan di perusahaan. Penelitian tersebut menemukan bahwa proses transfer informasi akan lebih mudah dan cepat dengan menggunakan e-mail seperti transfer dokumen, informasi, dan prosedur. Oleh karena itu, penerapan teknologi e-mail memberikan dampak untuk meningkatkan sistem komunikasi antara karyawan hingga manajemen di perusahaan yang lebih efektif dan dapat dilakukan dimana saja. Roman dan Rodriguez (2015) menguji teknologi yang diterapkan kepada salespeople di berbagai industri di Spanyol. Penggunaan teknologi terbukti mampu untuk meningkatkan keterampilan, lebih berfokus kepada pelanggan, dan performa kerja. Teknologi meningkatkan intrinsik motivasi karena teknologi akan meningkatkan dengan cepat keinginan untuk belajar menggunakan teknologi serta ketertarikan untuk menjual yang berorientasi pelanggan.

\section{Dampak Kenyamanan Penggunaan Teknologi}

Penggunaan teknologi tidak terlepas dari bagaimana teknologi tersebut nyaman untuk digunakan sehingga pengguna akan tertarik untuk menggunakan teknologi dalam jangka waktu yang lama. Persepsi kenyamanan (perceived enjoyment) tidak dibahas dalam model UTAUT tetapi persepsi kenyamanan sudah lebih dulu dijelaskan oleh Davis, Bagozzi, dan Warshaw (1992) yang digunakan sebagai transformasi intrinsik motivasi dalam teori motivasi (Deci 1972). Persepsi kenyamanan didefinisikan sebagai sejauh mana aktivitas menggunakan teknologi tertentu dipersepsikan dapat digunakan secara nyaman oleh dirinya sendiri, selain dari konsekuensi yang muncul dari penggunaan teknologi (Davis, Bagozzi, dan Warshaw 1992; Venkatesh 2000).

Kenyamanan menjadi konstruk umum yang digunakan untuk 
mengevaluasi pengalaman hedonis dari individu (Pe-Than, Goh, dan Lee 2015). Dinyatakan juga bahwa kenyamanan dipertimbangkan sebagai suatu konstruk dimensi tunggal dan dievaluasi sebagai bentuk kesenangan atau kegembiraan dalam melakukan perilaku (Wu, Wang, dan Tsai 2010). Kenyamanan dalam teknologi diartikan sebagai pengukuran item tunggal yang menilai seberapa nyaman individu menggunakan teknologi. Persepsi kenyamanan akan membantu dalam rangka penerimaan terhadap teknologi. Dalam beberapa kasus, kurangnya kenyamanan dalam menggunakan teknologi akan menghalangi penggunaan teknologi sehingga akan membutuhkan usaha yang lebih banyak untuk mempromosikan teknologi hingga dapat diterima.

Persepsi kenyamanan dijelaskan oleh Davis, Bagozzi, dan Warshaw (1992) sebagai persepsi yang mempengaruhi individu untuk mempunyai niat menggunakan teknologi. Dijelaskan oleh Venkatesh (2000) bahwa persepsi kenyaman yang dimiliki akan memberikan kepercayaan terhadap penggunaan teknologi yang akan membangun dan meningkatkan pengalaman dan mengurangi kecemasan terhadap penggunaan teknologi. Individu yang nyaman akan penggunaan teknologi cenderung akan menggunakan teknologi tersebut secara terus menerus di masa datang. Persepsi kenyamanan lebih lanjut diinvestigasi oleh Venkatesh (2008) melalui TAM 3 yang memiliki model penelitian lebih kompleks dibandingkan TAM yang sebelumnya maupun UTAUT. Penelitian tersebut menemukan bahwa persepsi merupakan konstruk yang menghadirkan persepsi kemudahaan (perceived ease of use) yang kemudian mewujudkan niat untuk menggunakan teknologi.

Penelitian ini akan menguji secara langsung bahwa persepsi kemudahan menjadi konstruk yang langsung akan mewujudkan niat untuk menggunakan teknologi. Selain itu, penelitian ini juga akan menguji hubungan persepsi kenyamanan menggunakan teknologi dalam kinerja individu yang dirasakan oleh karyawan. Davis, Bagozzi, dan Warshaw (1992) menjelaskan bahwa kenyamanan menggunakan teknologi akan mempengaruhi produktivitas menggunakan sistem oleh pengguna namun pengujian secara langsung belum dilakukan. Oleh karena itu, kedua relasi tersebut merupakan tindak lanjut atas relasi potensial yang belum pernah diuji secara langsung dalam teori-teori penerimaan teknologi. 


$$
\begin{aligned}
\mathrm{H}_{1}: & \text { Persepsi kenyamanan } \\
& \text { berpengaruh positif terhadap } \\
& \text { penggunaan teknologi } \\
\mathrm{H}_{2}: & \text { Persepsi kenyaman } \\
& \text { berpengaruh positif terhadap } \\
& \text { kinerja individu }
\end{aligned}
$$

\section{Pengaruh Lingkungan Terhadap Penggunaan Teknologi}

Lingkungan memiliki pengaruh dalam berbagai aspek kehidupan individu. Atas dampak yang luar biasa tersebut, teori keperilakuan seperti TPB memberikan perhatian dalam model penelitian yang dibangun untuk menginvestigasi pengaruh lingkungan dalam melakukan suatu perilaku. Pengaruh lingkungan dalam TPB disebut subjective norms yang berarti persepsi individu bahwa orang yang penting untuknya berfikir harus atau tidak dirinya menampilkan perilaku tertentu (Ajzen 1991). Penelitian dari Thompson, Higgins, dan Howell (1991) menjelaskan pengaruh lingkungan ke dalam konstruk social factor yang memiliki definisi seperti subjective norms dalam TPB.

Teori-teori dalam penerimaan teknologi juga mengadopsi pengaruh lingkungan sebagai faktor yang menstimulasi penerimaan teknologi. Venkatesh et al. (2003) dalam model UTAUT menggunakan social influence sebagai derajat yang mana individu mempersepsikan orang lain yang penting mendorongnya menggunakan sistem atau teknologi baru. Social influence sebagai determinan yang langsung mempengaruhi niat menggunakan teknologi. Rasionalisasi yang muncul didasarkan pada fakta bahwa perusahaan yang menerapkan suatu teknologi berupaya untuk mendorong karyawannya meninggalkan sistem yang lama (tradisonal) ke sistem yang baru (modern). Dalam hal ini manajemen dari sebuah perusahaan merupakan pihak yang dijadikan referensi dan atau sebagai orang yang memberikan pengauh sehingga teknologi baru digunakan.

Penelitian di area penerimaan teknologi telah banyak menggunakan pengaruh lingkungan sebagai faktor penerimaan teknologi. Berawal dari model UTAUT Venkatesh et al. (2003) yang menyediakan model penelitian dasar untuk berbagai penelitianpenelitian di area penerimaan teknologi. Venkatesh et al. (2003) dan Venkatesh (2008) menjelaskan secara umum bahwa pengaruh lingkungan mendorong terwujudnya niat untuk menggunakan teknologi. Abbasi et al. (2011) menemukan bahwa pengaruh lingkungan mampu mewujudkan niat untuk menggunakan teknologi dan juga meningkatkan persepsi kemudahan dan kemanfaatan dari 
suatu teknologi untuk menggunakan internet. Penelitian dari Tarhini et al. (2016) menemukan bahwa peran dari lingkungan sangat penting untuk mendorong menggunakan internet banking. Hasil yang sama juga ditemukan oleh Mckeown dan Anderson (2015) untuk kasus penggunaan e-learning di universitas. $\mathrm{H}_{3}$ : Lingkungan berpengaruh positif terhadap penggunaan teknologi

\section{Kondisi yang Memfasilitasi}

Kondisi yang memfasilitasi (facilitating condition) merupakan derajat yang mana individu percaya bahwa sebuah organisasi menyediakan infrastruktur teknis yang mendukung penggunaan sistem atau teknologi (Venkatesh et al. 2003). Kondisi yang memfasilitasi merupakan cerminan dari perceived behavioral control dalam TPB yang didefinisikan sebagai persepsi kendala internal dan eksternal pada perilaku yang mencakup kondisi yang memfasilitasi baik sumber daya maupun teknologi. Bukan sebuah keraguan jika kondisi yang memfasilitasi merupakan suatu faktor yang sangat penting dalam penggunaan sistem baru. Penggunaan sistem baru membutuhkan sumber daya yang tepat untuk mendukung sistem tersebut dapat digunakan.
Pertama, sumber daya manusia sebagai pengguna dari sistem harus diberikan sosialisasi atau pelatihan untuk meyakinkan kemampuannya dalam mengoperasikan sistem baru. Kedua, infrastruktur yang ada dalam perusahaan mendukung minimal requirement dari sistem yang akan diterapkan. Pada umumnya, sistem baru membutuhkan teknologi yang lebih canggih dari sistem yang sebelumnya, artinya perlu ada pembaharuan teknologi untuk mendukung sistem tersebut dijalankan di perusahaan.

Penelitian secara empiris telah mengindikasikan bahwa kondisi yang memfasilitasi memiliki pengaruh yang langsung terhadap penggunaan teknologi (behavioral usage) tanpa melalui niat (intention). Dampak dari kondisi yang memfasilitasi diharapkan akan meningkatkan pengalaman pengguna teknologi untuk dapat membantu dan mendukung penggunaan di seluruh organisasi sehingga hambatan akan terhapus (Venkatesh et al. 2003). Tarhini et al. (2016) setuju bahwa fasilitas yang mendukung akan mendorong penggunaan teknologi dalam hal ini adalah internet banking. Sementara itu Celik (2016) menemukan hal yang sama pada kasus online shopping. Williams, Rana, dan Dwivedi (2015) melalui 
telaah literatur dalam UTAUT menyimpulkan bahwa kondisi yang memfasilitasi merupakan suatu faktor yang langsung mempengaruhi penggunaan yang nyata terhadap teknologi. Dalam penelitian memberikan satu hipotesis yang menguji pengaruh antara kondisi yang memfasilitasi dengan kinerja individu. Peneliti menduga bahwa terdapat hubungan antara fasilitas dengan kinerja individu sehingga hipotesis tersebut dibuat.

$\mathrm{H}_{4}$ : Kondisi yang memfasilitasi berpengaruh positif terhadap penggunaan teknologi

$\mathrm{H}_{5}$ : Kondisi yang memfasilitasi berpengaruh positif terhadap kinerja individu

\section{Penggunaan Teknologi Terhadap}

\section{Kinerja Individu}

Teori-teori penerimaan teknologi pada umumnya menguji pada faktorfaktor yang mempengaruhi penggunaan teknologi yang dimediasi dengan niat (Venkatesh et al. 2003; Tarhini et al. 2016; Pe-Than, Goh, dan Lee 2015; Thompson, Higgins, dan Howell 1991). Akan tetapi, penjelasan lebih lanjut setelah teknologi digunakan terkait dengan dampaknya terhadap kinerja individu belum dijelaskan. Dalam UTAUT (Venkatesh et al. 2003) dan TAM (Davis 1989) memang sudah dijelaskan bahwa penggunaan teknologi dipengaruhi oleh adanya persepsi kemanfaatan yang berarti teknologi akan digunakan jika ada dampak yang diberikan. Akan tetapi masih sebatas persepsi sehingga belum dapat dijelaskan bahwa penggunaan teknologi memberikan pengaruh terhadap kinerja individu yang nyata (actual performance). Plewa et al. (2012) telah menjelaskan bahwa penggunaan teknologi akan mendorong peningkatan kinerja dan juga inovasi. Peneliti mengembangkan hipotesis untuk mengkonfirmasi persepsi kemanfaatan dalam UTAUT terhadap penggunaan teknologi yang berdampak pada kinerja individu.

$\begin{aligned} \mathrm{H}_{6}: \text { : } & \text { Penggunaan teknologi } \\ & \text { berpengaruh positif terhadap } \\ & \text { kinerja individu }\end{aligned}$

\section{METODE}

\section{Sampel dan Prosedur}

Penelitian ini menggunakan pendekatan kuantitatif untuk menguji model penelitian yang telah dibangun. Untuk memilih sampel, convenient sampling diterapkan dengan menyebar kuesioner yang berisi 28 pertanyaan yang ditujukan kepada karyawan perusahaan perangkat lunak (software). Penyebaran kuesioner dilakukan secara paper based dan online menggunakan google form. Partisipasi dalam 
penelitian ini bersifat sukarela tanpa ada paksaan sedikitpun. Responden diminta untuk mengisi kuesioner yang telah diberikan berdasarkan opini dan keyakinannya terhadap isi dari kuesioner tersebut. Peneliti menyebar 104 kuesioner paper based dengan jumlah kuesioner yang kembali dan dapat diolah sebanyak 80 kuesioner. Sedangkan, kuesioner secara online disebar sebanyak 80 dengan jumlah kuesioner yang valid 52. Sehingga, penelitian ini terdiri dari 132 data dari responden yang dapat diolah menggunakan alat statistic smartPLS 2.0.

\section{Pengukuran Variabel}

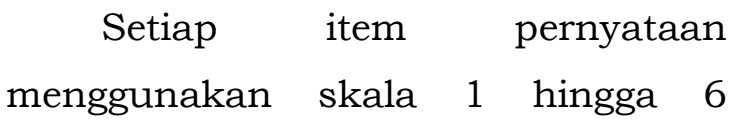

dengan deskripsi sebagai berikut. Skala 1 hingga 3 menjelaskan tentang tingkat perasaan tidak setuju dengan pernyataan yang disediakan di dalam kuesioner mulai dari sangat tidak setuju, tidak setuju, dan agak tidak setuju. Sebaliknya, skala 4 hingga 6 merupakan perasaan setudu dengan pernyataan di dalam kuesioner mulai dari agak setuju, setuju, dan sangat setuju. Seluruh variabel yang digunakan dalam penelitian ini diukur oleh pernyataan yang telah digunakan oleh penelitian sebelumnya terkait dengan UTAUT yang menyediakan informasi validitas dan reliabilitas dari masing-masing item. Tabel 1 di bawah ini menyajikan daftar variabel dengan disertai item pernyataan dan referensi.

Tabel 1. Pengukuran Variabel dan Referensi

\begin{tabular}{ccr}
\hline Variabel & Pengukuran & Referensi \\
\hline Persepsi Kenyamanan & 8 item & (Venkatesh dan Bala \\
\hline Pengaruh Lingkungan & 4 item & $\begin{array}{r}\text { (Venkatesh et al. 2003; } \\
\text { Thompson, Higgins, dan }\end{array}$ \\
\hline Kondisi yang Memfasilitasi & 3 item & $\begin{array}{c}\text { (Thompson, Higgins, } \\
\text { dan Howell 1991; Venkatesh }\end{array}$ \\
\hline Penggunaan Teknologi & 4 item & $\begin{array}{c}\text { (Thompson, Higgins, } \\
\text { dan Howell 1991; Venkatesh }\end{array}$ \\
\hline Kinerja Individu & 7 item & $\begin{array}{r}\text { (Plewa et al. 2012; } \\
\text { Moore dan Benbasat 1991) }\end{array}$
\end{tabular}


HASIL DAN PEMBAHASAN

\section{Evaluasi Model Pengukuran}

Evaluasi model pengukuran dilakukan untuk menilai validitas dan reliabilitas sebelum menguji model penelitian yang diajukan. Pengujian validitas dalam Partial Least Square (PLS) memiliki dua jenis yaitu convergent validity dan discriminant validity. Convergent validity mengkonfirmasi apakah masingmasing konstruk dapat direfleksikan dengan indikatornya sendiri (Gefen, Straub, dan Boudreau 2000). Untuk memenuhi convergent validity, nilai average variance extracted (AVE) dari masing-masing variabel di atas 0,5 dengan nilai loading masing-masing item lebih dari 0,5. Nilai loading kurang dari 0,5 harus dihapus karena akan menurunkan nilai AVE variabel.

Dalam penelitian ini terdapat beberapa item pernyataan yang dihapus karena nilai loading di bawah 0,5 . Sedangkan discriminant validity mengukur apakah pengukuran yang berbeda dari masing-masing konsep secara statistik berbeda (Gefen, Straub, dan Boudreau 2000). Discriminant validity berupa akar pangkat dua dari AVE dan cross loading. Akar pangkat dua dari AVE untuk masing-masing variabel harus lebih besar daripada korelasi terbesar antra variabel tersebut dengan variabel lain (Fornell dan Larcker 1981). Untuk membentuk reliabilitas, nilai dari composite reliability (CR) setidaknya memiliki nilai 0,6 tetapi akan lebih baik jika bernilai 0,7 (Hair et al. 2010). Berdasarkan tabel 3 di bawah, nilai AVE seluruh variabel lebih dari 0,5 dan akar pangkat dua AVE variabel lebih besar dari korelasinya ke variabel lain, dan nilai CR lebih dari 0,7 yang berarti telah memenuhi pengujian convergent validity, discriminant validity, dan reliabilitas.

Tabel 2. Reliabilitas, Convergent Validity, dan Discriminant Validity

\begin{tabular}{cccccccc}
\hline Variabe1 & AVE & CR & PK & PL & KM & PT & KI \\
\hline PK & 0,7396 & 0,9190 & $\mathbf{0 , 8 6 0 0}$ & & & & \\
PL & 0,6676 & 0,8885 & 0,6184 & $\mathbf{0 , 8 1 7 1}$ & & & \\
KM & 0,6610 & 0,8527 & 0,5242 & 0,7063 & $\mathbf{0 , 8 1 3 0}$ & & \\
PT & 0,6313 & 0,9112 & 0,4020 & 0,5433 & 0,5334 & $\mathbf{0 , 7 9 4 5}$ & \\
KI & 0,6197 & 0,9186 & 0,6106 & 0,6863 & 0,6340 & 0,6481 & $\mathbf{0 , 7 8 7 2}$ \\
\hline
\end{tabular}

Catatan: Angka diagonal dicetak tebal adalah $\checkmark$ AVE 
Evaluasi Model Struktural

Dalam pengujian model struktural dikenal istilah bootstrapping method yang digunakan untuk menguji signifikansi hubungan dalam model penelitian yang dibangun. Bootstraping adalah jalan alternatif untuk menghasilkan perkiraan yang lebih baik terhadap penelitian dengan sampel kecil. Teknik bootstrapping digunakan untuk menguji hipotesis (Beaumont dan Bocci 2009). Hair, Ringle, dan Sarstedt (2011) menjelaskan critical value untuk pengujian dua sisi (twotailed test) adalah 1,65 (level signifikansi $\quad 10 \%), \quad 1,96 \quad$ (level signifikansi 5\%), dan 2,58 (level signifikansi 1\%). Hubungan dikatakan signifikan jika t-value lebih dari level signifikansinya. Selain itu, path coefficient setidaknya bernilai 0,2 dengan nilai ideal 0,3 untuk dipertimbangkan sebagai sebuah hubungan yang kuat. Pengujian hipotesis dalam penelitian ini menggunakan pengujian dua sisi dengan level signifikansi 5\%. Tabel 4 di bawah ini meringkas hasil pengujian hipotesis dengan kesimpulannya.

Tabel 3. Path coefficient dan signifikansinya

\begin{tabular}{ccccc}
\hline & Jalur & Path & t-value & Hasil \\
\hline H & PK $\rightarrow$ PT & 0,0063 & $1,7369^{* *}$ & Didukung \\
H & PK $\rightarrow$ KI & 0,3197 & $16,3052^{*}$ & Didukung \\
H & PL $\rightarrow$ PT & 0,2994 & $7,0936^{*}$ & Didukung \\
H & KM $\rightarrow$ PT & 0,2872 & $10,4697^{*}$ & Didukung \\
H & KM $\rightarrow$ KI & 0,2646 & $11,2286^{*}$ & Didukung \\
H & PT $\rightarrow$ KI & 0,3784 & $15,9454^{*}$ & Didukung \\
\hline
\end{tabular}

Catatan: ${ }^{*}$ signifikansi $5 \%,{ }^{* *}$ signifikansi 10\%

Berdasarkan hasil dari pengujian hipotesis pada tabel 3 di atas, seluruh hipotesis yang dibangun dalam model penelitian didukung oleh data. Hanya $\mathrm{H}_{1}$ signifikan di level 10\%. Dengan demiikian persepsi kenyamanan, pengaruh lingkungan, dan kondisi yang memfasilitasi berpengaruh positif dan signifikan terhadap penerimaan terhadap sistem atau teknologi baru. Hasil yang lain menemukan bahwa persepsi kenyamanan, kondisi yang memfasilitasi, dan penggunaan teknologi berpengaruh positif dan signifikan terhadap kinerja individu. Temuan ini sangat penting untuk menjelaskan bahwa penggunaan teknologi telah terbukti mendorong kinerja individu. Temuan yang didasarkan pada konfirmasi persepsi kemanfaatan dalam model UTAUT. 
Dari pengujian nilai koefisien determinasi $\quad(r$ square $) \quad$ yang menunjukan kekuatan variabel independen untuk menjelaskan variabel dependen, nilai $r$ square penggunaan teknologi informasi 0,3425. Variabel independen persepsi kenyamanan, pengaruh sosial, dan kondisi yang memfasilitasi menjelaskan $34,25 \%$ dari penggunaan teknologi, 65,75\% dijelaskan oleh variabel lain. Nilai $r$ square kinerja individu 0,6082. Variabel independen persepsi kenyamanan, kondisi yang memfasilitasi, dan penggunaan teknologi menjelaskan $60,82 \%$ dari kinerja individu, sedangkan 39,18\% dijelaskan oleh variabel lain.

Persepsi kemudahan dalam menggunakan komputer akan mendorong penerimaan terhadap teknologi menjadi lebih cepat. Kenyamanan dalam menggunakan teknologi akan menjadi determinan yang lebih kuat meningkatkan kepercayaan untuk meggunakan teknologi karena akan menambah pengalaman, inovasi, dan mengembangkan persepsi usaha yang diperlukan untuk menyelesaikan suatu tugas (Venkatesh dan Bala 2008). Kenyamanan menggunakan teknologi secara kognitif mengarahkan untuk menggunakan teknologi (Pe-Than, Goh, dan Lee 2015).
Kenyamanan dengan teknologi merupakan variabel awal yang memunculkan persepsi bahwa teknologi tersebut mudah digunakan (Davis 1989). Persepsi kemudahan yang muncul akan menstimulasi pikiran dari individu untuk menggunakan teknologi tersebut dalam jangka waktu yang panjang. Persepsi kemudahan memiliki hubungan dengan persepsi kemanfaatan (Venkatesh dan Bala 2008) yang artinya kemudahan menggunakan teknologi akan memberikan manfaat kepada pengguna terhadap aktivitasnya. Dengan demikian, kenyamanan akan membawa individu pada manfaat dari teknologi yang pada akhirnya akan mendukung kinerja individu seperti yang telah dibuktikan pada $\mathrm{H}_{2}$.

Pengaruh lingkungan telah menjadi faktor yang kuat untuk mempengaruhi individu baik untuk berperilaku (TPB) maupun penerimaan terhadap teknologi (UTAUT) (Ajzen 1991; Venkatesh et al. 2003). Penelitian ini juga memiliki hasil yang sama bahwa orang yang dianggap penting dan lingkungan sosial berperan dalam mempengaruhi penerimaan teknologi seperti yang sudah ditemukan penelitian lain di bidang penerimaan teknologi (Ajzen 1991; Venkatesh et al. 2003; Venkatesh dan Bala 2008; Tarhini et 
al. 2016; Mckeown dan Anderson 2015; Plewa et al. 2012). Karyawan perusahaan perangkat lunak memiliki pengetahuan tinggi akan teknologi dan perkembangannya. Tanpa diragukan lagi bahwa pembaharuan teknologi di zaman sekarang ini hanya membutuhkan waktu yang sangat singkat. Karenanya, karyawan di lingkungan kerja akan selalu menangkap perkembanganperkembangan kaitannya dengan teknologi sehingga akan sangat mudah sekali untuk menerima berbagai perkembangan sistem dan teknologi. Pengaruh dari rekan kerja yang terlebih dahulu memiliki pengetahuan akan perkembangan teknologi akan mempengaruhi rekan lainnya untuk berinovasi dengan perkembangan tersebut.

Kondisi yang memfasilitasi merupakan bentuk kesadaran dari organisasi untuk memberikan dukungan kepada karyawannya untuk menggunakan teknologi atau sistem. Dukungan tidak hanya berbentuk fisik seperti perangkat computer dan internet tetapi juga mencangkup pada dukungan untuk meningkatkan sumber daya manusia seperti diberikan pelatihan maupun sosialisasi. Penelitian menemukan bahwa kondisi yang memfasilitasi memainkan peran penting dalam penggunaan teknologi (Tarhini et al.
2016; Venkatesh et al. 2003). Hasil penelitian ini mendukung penelitian sebelumnya bahwa fasilitas sangat penting untuk mendorong penggunaan teknologi. Di perusahaan pengembang perangkat lunak, fasilitas infastruktur STI menjadi kebutuhan yang fundamental. Karyawan pada dasarnya sangat erat kaitannya dengan penggunaan STI sehingga adanya infrastruktur yang memadai akan mendorong penggunaan teknologi. Temuan ini juga membuktikan perceived behavioral control dalam TPB yang mengindikasikan bahwa adanya kondisi yang memfasilitasi akan memberikan kemudahan dalam menggunakan STI. Di aspek lain dalam fasilitas pengembangan sumber daya manusia, pelatihan menjadi sesuatu yang penting untuk diterapkan sebelum dan sesudah implementasi STI (Venkatesh dan Bala 2008). Pemberian fasilitas pelatihan memberikan pengetahuan dan keyakinan untuk meningkatkan kemampuan mengggunakan STI serta menjaga keberlangsungan penggunaan STI. Di lain sisi, temuan penelitian ini menjelaskan bahwa kondisi yang memfasilitasi memberikan pengaruh terhadap kinerja individu dari karyawan. Pemberian fasilitas teknologi maupun peningkatan sumber daya secara 
langsung menyediakan keyakinan bahwa hal tersebut mendorong kinerja individu untuk lebih produktif.

Penelitian ini menemukan penggunaan teknologi (actual) memberikan dampak pada kinerja individual. Temuan ini adalah konfirmasi dari ekspektasi performa (performance expectancy) di UTAUT. UTAUT hanya menjelaskan bahwa penggunaan teknologi didasari pada adanya harapan untuk meningkatkan performa. Namun demikian, UTAUT belum menjelaskan dampak penggunaan teknologi pada performa nyata (actual performance). Apa yang ditemukan dalam penelitian ini telah mengkonfirmasi bahwa dengan penggunaan teknologi kinerja dari individu akan terdukung. Sehingga terdapat dua hubungan yang melibatkan tiga variabel antara harapan performa, penggunaan teknologi, dan performa nyata. Pertama, harapan performa akan mendorong individu untuk menggunakan teknologi seperti yang dibuktikan dalam UTAUT (Venkatesh et al. 2003; Tarhini et al. 2016; Mckeown dan Anderson 2015). Kedua, penggunaan teknologi telah terbukti secara empiris mempengaruhi kinerja dari individu.

Secara keseluruhan, penelitian ini memberikan gambaran bahwa penggunaan teknologi memiliki dampak yang signifikan terhadap kinerja seluruh individu di dalam perusahaan dengan dipengaruhi oleh berbagai faktor sebelumnya (lihat Gambar 3). Sebagai contoh pada pekerjaan bidang akuntansi, penggunaan STI menjadi pilar penting untuk proses pengolahan data transaksi yang dapat dikerjakan secara semi-otomatis atau bahkan otomatis untuk membuat sebuah laporan keuangan atau laporan lainnya yang dapat disajikan ke dalam waktu tertentu. Penggunaan STI membuat kinerja akuntan menjadi lebih mudah serta produktivitas dalam pemrosesan data transaksi akan meningkat. Siklus akuntansi dengan berbagai langkah di dalamnya telah disadari membuat pekerjaan seorang akuntan sangat rumit sehingga STI menjadi pendukung yang tepat bagi akuntan untuk menyelesaikan pekerjaan siklus akuntansi tersebut. Walaupun dengan fenomena penggunaan STI di bidang akuntansi berdampak pada berubahnya "pekerjaan asli" seorang akuntan menjadi petugas input dan pemeriksa output dari suatu sistem akuntansi (Chen et al. 2012). 


\section{KESIMPULAN, IMPLIKASI DAN} KETERBATASAN PENELITIAN

Penelitian ini bertujuan untuk menguji faktor yang berpengaruh terhadap penggunaan atau penerimaan teknologi. Selain itu, terdapat tujuan khusus untuk menguji faktor yang mempengaruhi kinerja individual akibat dari penggunaan teknologi. Penelitian ini menggunakan model UTAUT yang dikenal sebagai model pondasi dalam menginvestigasi perilaku di bidang sistem informasi. Penelitian ini juga memberikan konfirmasi terhadap persepsi kemanfaatan dalam UTAUT untuk diteliti lebih jauh pengaruh teknologi terhadap performa atau kinerja individu yang sebenarnya (Plewa et al. 2012). Temuan dalam penelitian ini pada dasarnya secara teori dan empiris memiliki hasil yang sama pada relasi yang tersedia pada model UTAUT (lihat model penelitian di atas). Secara umum, penerapan teknologi (baru) mudah diterima oleh para karyawan di perusahan perangkat lunak di Yogyakarta.

Seperti yang sudah ada pada penelitian sebelumnya di area STI bahwa hasil penelitian ini mungkin tidak dapat digeneralisasikan karena hanya berasal dari satu obyek penelitian. Penelitian ini hanya menggunakan sedikit variabel yang tersedia dalam model UTAUT.
Penggunaan seluruh model UTAUT akan menambah penjelasan yang lebih komprehensif. Selain itu, penambahan variabel di luar UTAUT perlu ditambah seperti yang tersedia dalam model TAM 3 serta arahan penelitian selanjutnya dari Venkatesh dan Bala (2008) seperti pelatihan, dukungan perusahan, dan lain-lain. Penelitian ini masih menjelaskan secara umum penerimaan terhadap suatu teknologi tetapi belum menjelaskan secara spesifik teknologi apa yang diterapkan di perusahaan.

Penelitian berikutnya diharapkan untuk penelitian yang bersifat konfirmasi dapat menggunakan expectation discomfirmation theory (EDT) (Churchill Jr dan Surprenant 1982) sebagai teori dasar untuk menginvestigasi setelah penggunaan teknologi. Penelitian berikutnya dapat menjelaskan secara spesifik suatu teknologi yang diterima atau diterapkan seperti penggunaan software atau infrastruktur TI tertentu di dalam maupun luar perusahaan. Akhirnya, walaupun penelitian ini menggunakan pendekatan kuantitatif dan tujuan penelitian sudah terpenuhi, untuk memperkuat pembahasan lebih baik jika penelitian ini diterapkan dengan mix-method approach. 


\begin{abstract}
Penelitian ini berimplikasi memberikan gambaran tentang penerimaan teknologi di area para karyawan perusahaan pengembang perangkat lunak di Yogyakarta. Penelitian ini juga memberikan pengetahuan tentang konfirmasi dari performance expectancy dalam UTAUT untuk menjadi actual performance.
\end{abstract}

\section{REFERENSI}

Abbasi, Muhammad Sharif., Fida Hussain Chandio, Abdul Fatah Soomro, dan Farwa Shah. 2011. "Social Influence, Voluntariness, Experience and the Internet Acceptance: An Extension of Technology Acceptance Model within a South-Asian Country Context." Journal of Enterprise Information Management 24 (1): 30-52.

Ajzen, Icek. 1991. "The Theory of Planned Behavior." Organizational Behavior and Human Decision Processes 50: 179-211.

Balzli, Catherine Equey., dan Bernard Morard. 2012. "The Impact of an Integrated Financial System Implementation on Accounting Profiles in a Public Administration: An Ethnographic Approach." Journal of Accounting $\&$ Organizational Change 8 (3): 364-85.

Bandura, Albert. 1977. "Self-Efficacy: Toward a Unifying Theory of Behavioral Change." Psychological Review 84 (2): 191215.

- 1999. "Social Cognitive Theory: An Agentic Perspective."
Asian Journal of Social Psychology 2: 21-41.

Beaumont, J F., dan Cynthia Bocci. 2009. "A Practical Bootstrap Method for Testing Hypotheses from Survey Data." Survey Methodology 35 (1): 25-35.

Celik, Hakan. 2016. "Customer Online Shopping Anxiety within the Unified Theory of Acceptance and Use Technology (UTAUT) Framework." Asia Pacific Journal of Marketing and Logistics 28 (2): 278-307.

Chen, Hsueh-Ju, Shaio Yan Huang, An-An Chiu, dan Fu-Chuan Pai. 2012. "The ERP System Impact on the Role of Accountants." International Management \& Data Systems 112 (1): 83-101.

Chesley, Noelle. 2005. "Blurring Boundaries ? Linking Technology Use , Spillover , Individual Distress , and Family Satisfaction." Journal of Marriage and Family 67: 1237-48.

Chesley, Noelle., dan Britta E. Johnson. 2015. "Technology Use and the New Economy: Work Extension, Network Connectivity, and Employee Distress and Productivity." Work and Family in the New Economy 26: 61-99.

Churchill Jr, Gilbert A., dan Carol Surprenant. 1982. "An Investigation Into Customer the Determinants of Satisfaction." Amerrican Marketing Association 19 (4): 491-504.

Compeau, Deborah., Christopher A. Higgins, dan Sid Huff. 1999. "Social Cognitive Theory and Idividual Reactions to Computing Technology: A Longitudinal Stuudy." MIS Quarterly 23 (2): 145-58.

Compeau, Deborah R., dan Christopher A. Higgins. 1995. "Application of Social Cognitive Theory to Training for Computer Skills." Information sSystem Research 6 (2): 118-43.

Davis, Fred D. 1989. "Perceived Usefulness, Perceived Ease of 
Use, and User Acceptance of Information Technology." MIS Quarterly 13 (3): 319-40.

Davis, Fred D., Richard P. Bagozzi, dan Paul R. Warshaw. 1992. "Extrinsic and Intrinsic Motivation to Use Computers in the Workplace'." Journal of Apllied Social Psychology 22 (14): 1111-32.

Deci, Edward L. 1972. "Intrinsic Motivation , Extrinsic Reinforcement , And Inequity." Journal of Personality and Social Psychology 22 (1): 113-20.

Fornell, Claes., dan David Larcker. 1981. "Evaluating Structural Equation Models with Unobservable Variables and Measurement Error." Amerrican Marketing Association 18 (1): 3950.

Gefen, David., Detmar W. Straub, dan Marie Claude Boudreau. 2000. "Structural Equation Modeling and Regression: Guidelines for Research Practice." Commucication of the Association for Information Systems 4 (1): 177.

Gordon, Steven., Monideepa Tarafdar, Robert Cook, Richard Maksimoski, dan Bernice Rogowitz. 2008. "Improving the Front End of Innovation with Information Technology." Research Technology Management 51 (3): 50-59.

Hair, Joseph F., William C. Black, Barry J. Babin, Rolph E. Anderson, dan Ronald L. Tatham. 2010. Multivariate Data Analysis. New Jersey: Prantice Hall.

Hair, Joseph F., Christian M. Ringle, dan Marko Sarstedt. 2011. "PLSSEM: Indeed a Silver Bullet." The
Journal of Marketing Theory and Practice 19 (2): 139-52.

Hidalgo, Antonio., dan Jose Albors. 2008. "Innovation Management Techniques and Tools: A Review from Theory and Practice." $R \& D$ Management 38 (2): 113-27.

Lindsay, Rachael., Thomas W. Jackson, dan Louise Cooke. 2011. "Adapted Technology Acceptance Model for Mobile Policing Article Information:" Journal of Systems and Information Technology 13 (4): 389-407.

Mano, Rita S., dan Gustavo S. Mesch. 2010. "Computers in Human Behavior E-Mail Characteristics , Work Performance and Distress." Computers in Human Behavior 26 (1): 61-69.

Mckeown, Tui., dan Mary Anderson. 2015. "UTAUT : Capturing Differences in Undergraduate versus Postgraduate Learning?" Education + Training 28 (3): 94565.

Moore, Gary C., dan Izak Benbasat. 1991. "Development of an Instrument to Measure the Perceptions of Adopting an Information Technology Innovation." Information System Research 2 (3): 192-223.

Mosweu, Olefhile., Kelvin Bwalya, dan Athulang Mutshewa. 2016. "Examining Factors Affecting the Adoption and Usage of Document Workflow Management System ( DWMS ) Using the UTAUT Model Case of Botswana." Records Management Journal 26 (1): 38-67.

Pe-Than, Ei Pa Pa., Dion Hoe-Lian Goh, dan Chei Sian Lee. 2015. "Why Do People Play Human Computation Games? Effects of 
Perceived Enjoyment and Perceived Output Quality." Aslib Journal of Information Management 67 (5): 592-612.

Plewa, Carolin., Indrit Troshani, Anthony Francis, and Giselle Rampersad. 2012. "Technology Adoption and Performance Impact in Innovation Domains." Industrial Management \& Data Systems 112 (5): 748-65.

Roman, Sergio, dan Rocio Rodriguez. 2015. "The Influence of Sales Force Technology Use on Outcome Performance." Journal of Business \& Industrial Marketing 30 (6): 771-83.

Sriram, Ram S. 1995. "Accounting Information System Issues of FMS." Integrated Manufacturing System 6 (1): 35-40.

Tarhini, Ali., Mazen El-Masri, Maged Ali, dan Alan Serrano. 2016. "Extending the UTAUT Model to Understand the Customers , Acceptance and Use of Internet Banking in Lebanon A Structural Equation Modeling Approach." Information Technology \& People 29 (4): 830-49.

Thompson, Ronald L., Christopher A. Higgins, dan Jane $M$ Howell. 1991. "Personal Computing: Toward a Conceptual Model of Utilization." MIS Quarterly 15 (1): 125-43.

Venkatesh, Viswanath. 2000. "Determinants of Perceived Ease of Use: Integrating Control, Intrinsic Motivation, and Emotion into the Technology Acceptance Model." Information System Research 11 (4): 342-65.

Venkatesh, Viswanath., dan Hillol Bala. 2008. "Technology Acceptance Model 3 and a Research Agenda on
Interventions." Decision Sciences 39 (2): 273-315.

Venkatesh, Viswanath., Michael G. Morris, Gordon B Davis, dan Fred D Davis. 2003. "User Acceptance of Information Technology: Toward a Unified View." MIS Quarterly 27 (3): 42578.

Williams, Michael D., Nripendra P. Rana, dan Yogesh K. Dwivedi. 2015. "The Unified Theory of Acceptance and Use of Technology (UTAUT): A Literature Review." Journal of Enterprise Information Management 28 (3): 443-88.

Wu, Jen-her., Shu-ching Wang, dan Ho-huang Tsai. 2010. "Computers in Human Behavior Falling in Love with Online Games: The Uses and Gratifications Perspective." Computers in Human Behavior 26 (6): 1862-71. 